\title{
Tinjauan Yuridis Terhadap Perjanjian Surrogate Mother Yang Tertuang Dalam Akta Notaris Di Indonesia
}

\author{
Kenyatun \\ Fakultas Hukum Universitas Islam Indonesia Yogyakarta Indonesia \\ Jln. Cik Di Tiro No. 1 Yogyakarta 55223 Indonesia \\ kennyatun13@gmail.com
}

\begin{abstract}
This study aims to analyze the legal position of surrogate mother agreement according to the Indonesiam Civil Code and Islamic law and the implementation of surrogate mother agreement made in the form of a notary deed in Indonesia. This is a normative legal research that uses a statutory approach. The results of the study conclude that the surrogate mother agreement in the perspective of civil law is considered invalid because it violates the nature of the object of the agreement while the rental of uterus according to Islamic law is unlawful as confirmed in the fatwa and individual opinions based on the Qur'an. In addition, if the surrogate mother agreement is contained in a notary deed, then the deed becomes null and void.
\end{abstract}

Key Words: Agreement; notary deed; surrogate mother

\begin{abstract}
Abstrak
Penelitian ini bertujuan untuk menganalisis kedudukan perjanjian sewa rahim (surrogate mother) menurut Kitab Undang-Undang Hukum Perdata serta hukum Islam dan pelaksanaan perjanjian sewa rahim atau surrogate mother yang dibuat dalam bentuk akta Notaris di Indonesia. Penelitian ini merupakan penelitian hukum normatif yang menggunakan metode pendekatan berupa pendekatan perundang-undangan (statue approach). Hasil penelitian menyimpulkan bahwa perjanjian/ perikatan sewa rahim dalam perspektif hukum perdata dianggap tidak sah karena menyalahi hakikat dari objek perjanjian/perikatan sementara sewa Rahim menurut hukum Islam hukumnya haram sebagaimana ditegaskan dalam ketetapan fatwa maupun pendapat individu yang berdasar pada Al-Quran. Selain itu, apabila perjanjian sewa rahim (surrogate mother) tersebut termuat dalam akta Notaris maka akta tersebut menjadi batal demi hukum.
\end{abstract}

Kata-kata Kunci: Akta notaris; perjanjian; surrogate mother 


\section{Pendahuluan}

Pasal 1 Undang-Undang Nomor 1 Tahun 1974 tentang Perkawinan menyatakan bahwa perkawinan adalah ikatan lahir batin antara seorang pria dengan seorang wanita sebagai suami istri dengan tujuan membentuk keluarga yang bahagia dan kekal berdasarkan Ketuhanan Yang Maha Esa. Tujuan perkawinan adalah untuk membentuk suatu keluarga yang bahagia dan kekal. Keluarga dalam pengertian ini adalah suatu kesatuan yang terdiri dari ayah, ibu, dan anak. ${ }^{1}$ Namun pada kenyataannya, tidak semua pasangan dapat membentuk sebuah keluarga atau melahirkan anak. Hal ini dapat dikarenakan beberapa hal seperti adanya penyakit yang mengakibatkan pasangan suami istri tidak dapat melahirkan keturunan. Hal tersebut tentu saja menimbulkan keputusasaan bagi pasangan suami istri yang ingin mempunyai keturunan. Keputusasaan pasangan suami istri yang tidak dapat melahirkan keturunan biasanya yang melatarbelakangi suami untuk melakukan praktik poligami demi memperoleh buah hati dari wanita lain, dengan catatan wajib untuk mendapat persetujuan dari istri baik secara tertulis maupun secara lisan yang diatur dalam ketentuan Pasal 40 dan Pasal 41 Peraturan Pemerintah Nomor 9 Tahun 1975 tentang Pelaksanaan Undang-Undang Nomor 1 Tahun 1974 tentang Perkawinan.

Namun dalam perkembangannya, kemajuan teknologi dalam bidang kedokteran menemukan cara pengawetan sperma dan metode pembuatan di luar rahim atau yang dikenal dengan sebutan In Vitro Fertilization (IVF) pada tahun 1970-an. In Vitro Fertilization (IVF), yaitu terjadinya penyatuan/ pembuahan benih laki-laki pada benih wanita pada suatu cawan petri (di laboratorium), yang mana setelah terjadinya penyatuan tersebut (zygote) akan diimplantasikan atau ditanam kembali di rahim wanita, yang biasanya pada wanita yang punya benih tersebut (program bayi tabung) atau ditanamkan pada rahim wanita lain yang tidak mempunyai hubungan sama sekali dengan sumber benih tersebut. Untuk hal ini dilakukan melalui perjanjian sewa (surrogacy) yang dikenal dengan istilah surrogate mother (ibu pengganti). ${ }^{2}$

Di Indonesia, kasus surrogate mother yang santer terdengar untuk pertama kalinya yaitu pada Januari 2009 ketika artis Zarima Mirasfur diberitakan melakukan penyewaan rahim untuk bayi tabung dari pasangan suami istri pengusaha yang berasal dari Surabaya. Ferry Juan, pengacara Zarima, mengatakan bahwa Zarima mendapat imbalan mobil dan uang sebesar lima

${ }^{1}$ R. Soetojo Prawirohamidjojo, Pluralisme Dalam Perundang-Undangan Perkawinan di Indonesia, Airlangga University Press, Surabaya 1998, hlm. 38.

2Dezriza Ratman, Surrogate Mother Dalam Perspektif Etika dan Hukum; Bolehkah Sewa Rahim di Indonesia?, PT. Media Elex Komputindo, Jakarta, 2012, hlm. 2. 
puluh juta rupiah dari penyewaan rahim tersebut. Kasus surrogate mother juga banyak terjadi di luar negeri, selebritis papan atas dunia Kim Kardashian dan Kanye West memperoleh keturunan dengan menggunakan metode surrogate mother.

Pasal 12 Undang-Undang Nomor 36 Tahun 2009 tentang Kesehatan (UU Kesehatan) diatur bahwa upaya kehamilan di luar cara alamiah hanya dapat dilakukan oleh pasangan suami istri yang sah dengan ketentuan: (1) hasil pembuahan sperma dan ovum dari suami istri yang bersangkutan ditanamkan dalam rahim istri dimana ovum berasal; (2) dilakukan oleh tenaga kesehatan yang mempunyai keahlian dan kewenangan untuk itu; (3) pada fasilitas pelayanan kesehatan tertentu. Pasal tersebut menunjukkan bahwa metode atau kehamilan di luar cara alamiah hanya dapat dilakukan melalui cara bayi tabung saja. Selain itu, dijelaskan kembali dalam Pasal 2 ayat (3) Peraturan Menteri Kesehatan Nomor 039/Menkes/SK/2010 tentang Penyelenggaraan Pelayanan Teknologi Reproduksi Buatan bahwa pelayanan teknologi reproduksi buatan hanya dapat diberikan kepada pasangan suami istri yang terkait perkawinan yang sah dan sebagai upaya akhir untuk memperoleh keturunan serta berdasarkan suatu indikasi medik. Berdasarkan kedua peraturan tersebut, dapat dikatakan bahwa metode kehamilan di luar cara alamiah hanya boleh dilakukan melalui metode bayi tabung dan terhadap pasangan suami istri yang sah.

Sewa rahim sangat erat kaitannya dengan perjanjian sewa menyewa. Terkait hal ini, Pasal 1313 Kitab Undang-Undang Hukum Perdata (KUHPerdata) menyatakan bahwa suatu perjanjian adalah suatu perbuatan dimana suatu orang mengikatkan diri terhadap satu orang lain atau lebih. Lahirnya perjanjian, apabila terdapat dua orang atau lebih mengikatkan diri satu sama lain dan berjanji untuk menunaikan prestasi tertentu. Landasan hukum mengenai perjanjian sewa rahim belum diatur secara rinci dalam peraturan perundang-undanganmnamun secara yuridis terdapat bebrapa pasal dalam KUHPerdata yang dapat dipergunakan untuk mengkaji substansi dari perjanjian sewa rahim, yaitu Pasal 1320 KUHPerdata. ${ }^{3}$ Selain itu, didalam perjanjian sewa rahim, apabila dikaitkan dengan syarat sahnya perjanjian menurut Pasal 1320 KUHPerdata, terdapat beberapa hal yang perlu dipertanyakan. Salah satunya adalah mengenai hal tertentu yang diatur dalam perjanjian sewa rahim, yang dalam ketentuan Pasal 127 Undang-Undang Kesehatan disebutkan bahwa teknologi reproduksi untuk membantu kehamilan di luar alamiah hanya dapat dilakukan dengan metode bayi tabung. 
Hukum perjanjian menganut asas kebebasan berkontrak sebagaimana dinyatakan dalam Pasal 1338 KUHPerdata yang menyebutkan bahwa semua perjanjian yang dibuat secara sah berlaku sebagai undang-undang bagi mereka yang membuatnya. Hal ini berarti bahwa para pihak dalam suatu perjanjian bebas untuk menentukan materi/isi dari perjanjian. Sementara jika dihubungkan dengan syarat sahnya perjanjian, bagaimana kedudukan dari perjanjian tersebut ketika dalam suatu perjanjian sewa rahim kedua belah pihak, yaitu pasangan suami istri dan calon ibu pengganti sama-sama bersedia dan telah bersepakat untuk melakukan perjanjian sewa rahim tersebut.

Selain dilihat melalui peraturan perundang-undangan, permasalahan mengenai perjanjian sewa rahim ini juga harus dipandang dari segi etika serta agama. Indonesia merupakan negara yang sebagian besar penduduknya menganut agama Islam dan hukum dalam ajaran agama Islam juga dijadikan sebagai salah satu sumber hukum positif di Indonesia yang menjelaskan bahwa dalam Islam tidak mengenal penitipan janin kepada wanita lain. Selain itu, lahirnya bayi dari hasil perjanjian sewa rahim akan menimbulkan permasalahan hukum seperti penentuan nasab sang anak dan siapakah yang menjadi ibu yang sesungguhnya, serta terkait pembagian waris terkait lahirnya anak dari hasil perjanjian sewa rahim.

Pengertian sewa rahim adalah menggunakan rahim wanita lain untuk mengandung benih wanita (ovum) yang telah disenyawakan dengan benih lakilaki (sperma) dan janin itu dikandungkan oleh wanita tersebut hingga lahir. Kemudian anak itu diberikan kembali kepada pasangan suami isteri itu untuk memliharanya dan anak tersebut dianggap anak mereka. ${ }^{4}$ Para ulama mengharamkan sewa rahim jika menggunakan rahim wanita selain isteri, mencampurkan benih antara suami dan wanita lain, mencampurkan benih isteri dengan laki-laki lain, atau memasukkan benih yang dibuahi setelah kematian suami isteri. ${ }^{5}$

Setiap muslim memiliki kewajiban untuk melaksanakan kaidah-kaidah atau peraturan-peraturan hukum Islam yang ditunjuk oleh peraturan-peraturan yang jelas (nash-nash yang sharib). Selama peraturan tersebut ditunjukkan oleh peraturan lain yang menyebutkan ketidakwajibannya, maka setiap ketentuan hukum agama Islam wajib dilaksanakan selama tidak ada ketentuan lain (yang

${ }^{4}$ Radin Seri Nabahan bt. Ahmad Zabidi, 2007, Penyewaan Rabim Menurut Pandangan Islam, Pustaka Utama, Bandung, 2007, hlm. 2.

${ }^{5}$ Ibid., hlm. 5. 
datang kemudian sesudah ketentuan terdahulu) yang menyatakan ketentuan terdahulu tidak wajib. 6

Permasalahan dalam surrogate mother adalah karena anak yang lahir dalam kasus surrogate mother belum jelas nasabnya. Prosesnya hampir sama dengan bayi tabung namun proses kehamilannya dilakukan pada rahim wanita lain mengingat sel telur dan spermanya berasal dari pasangan suami istri akan tetapi anak tersebut dibesarkan dan dilahirkan dari rahim wanita lain. Proses kehamilan di rahim wanita lain inilah yang menjadi permasalahan. Hal ini dikarenakan pada rahim wanita lain tersebut terjadi fase-fase perkembangan janin, dan pertumbuhan janin semakin sempurna dengan ditiupkan ruh ke dalamnya. Hal ini dikuatkan dengan hadist Nabi yang berbunyi, "setiap kamu dikumpulkannya dalam rahim ibumu selama 40 hari, kemudian menjadi gumpalan daging juga dalam masa 40 hari. Setelah itu Allah mengutus malaikat untuk melengkapi 4 hal, yaitu amal, akal, rezeki, sengsara dan bahagia. Barulah setelah itu ditiupkan ruh ke dalamnya."7 Selain itu, surrogate mother juga bukan tanpa risiko, ibu yang menyewakan rahim bisa saja melarikan diri yang tentu jelas akan merugikan pihak yang menyewa rahim. Motif-motif dalam terjadinya surrogate mother juga bisa dijadikan modus kejahatan human trafficking bagi pihak-pihak yang tidak bertanggungjawab. Oleh sebab itu, praktik surrogate mother masih perlu kajian yang sangat dalam mengenai pelaksanaannya.

Permasalahan lainnya yaitu pembagian waris dari anak hasil perjanjian sewa rahim yaitu berkaitan dengan bagaimana kedudukan perjanjian sewa rahim atau surrogate mother menurut Kitab Undang-Undang Hukum Perdata dan bagaimana penerapannya dalam praktik kenotariatan serta implikasi hukum terhadap akta yang mengatur tentang hal tersebut. Pengertian Notaris berdasarkan ketentuan Pasal 1 angka 1 Undang-Undang Nomor 2 Tahun 2014 tentang Perubahan atas Undang-Undang Nomor 30 Tahun 2004 tentang Jabatan Notaris (Undang-Undang Jabatan Notaris) adalah pejabat umum yang berwenang untuk membuat akta otentik dan memiliki kewenangan lainnya sebagaimana dimaksud dalam undang-undang ini atau berdasarkan undangundang lainnya. Jadi, Notaris adalah pejabat umum yang secara khusus diberikan wewenang oleh undang-undang untuk membuat suatu alat bukti yang otentik (mempunyai kekuatan pembuktian yang sempurna).

Akta Notaris atau akta otentik yaitu akta yang pembuatannya dari awal dimulai dari tindakan menghadap sampai pada akhir atau penandatanganan akta

${ }^{6}$ Suhrawardi K. Lubis dan Komis Simanjuntak, Hukum Waris Islam, Cetakan Keempat, Sinar Grafika, Jakarta, 2004, hlm. 3.

${ }^{7}$ Ahmad Husairi, Kontribusi Embriologi dalam Penetapan Hukum Figih Kehamilan, Cetakan Pertama, Pustaka Banua, Yogyakarta, 2007, hlm. 15. 
itu semuanya tunduk pada aturan-aturan hukum dalam hal ini tunduk pada Undang-Undang Jabatan Notaris. Berkaitan dengan hal ini, Pasal 1868 KUHPerdata menyatakan bahwa suatu akta otentik ialah suatu akta yang dibuat dalam bentuk yang ditentukan undang-undang oleh atau dihadapan pejabat umum yang berwenang untuk itu di tempat akta itu dibuat. Notaris sebagai pejabat umum diberikan oleh peraturan perundang-undangan kewenangan untuk membuat segala perjanjian dan akta serta yang dikehendaki oleh yang berkepentingan, termasuk akta otentik, sebagaimana ditegaskan dalam Pasal 15 Undang-Undang Jabatan Notaris. Selaku pejabat pembuat akta otentik, seorang Notaris dalam tugasnya melekat pula kewajiban yang harus dipatuhi, karena kewajiban tersebut merupakan sesuatu yang harus dilaksanakan sebgaimana diatur dalam Pasal 16 ayat (1) sampai ayat (13) Undang-Undang Jabatan Notaris. Berkaitan dengan tugas dan kewenangan Notaris tersebut, tidak mustahil di kemudian hari Notaris akan diperhadapkan pada situasi dimana para penghadap datang untuk minta dibuatkan suatu bukti berupa akta otentik tentang perbuatan hukum mereka terkait perjanjian surrogate mother. Berdasarkan uraian tersebut, maka Penulis tertarik untuk mengkaji dan mengangkat judul penelitian Peran Notaris Dalam Pembuatan Akta Waris Terkait Surrogate Mother.

Berdasarkan hasil penelusuran dan pemeriksaan yang telah dilakukan di kepustakaan maupun di internet, penelitian tentang "Peran Notaris Dalam Pembuatan Akta Waris Terkait Surrogate Mother" belum pernah dilakukan. Pendapat atau temuan orang lain yang terdapat dalam penulisan ini dikutip atau dirujuk berdasarkan kode etik ilmiah. Oleh karena itu, dapat disimpulkan bahwa penelitian ini adalah asli adanya sehingga secara akademik penelitian ini dapat dipertanggungjawabkan kemurniannya. Penelitian ini akan mengkaji mengenai kedudukan perjanjian sewa rahim atau surrogate mother menurut Kitab UndangUndang Hukum Perdata dan Hukum Islam serta pelaksanaan perjanjian sewa rahim atau surrogate mother yang dibuat dalam bentuk akta Notaris di Indonesia.

\section{Rumusan Masalah}

Berdasarkan uraian latar belakang tersebut, rumusan masalah dalam penelitian ini ialah: pertama, bagaimana kedudukan perjanjian sewa rahim atau surrogate mother menurut Kitab Undang-Undang Hukum Perdata dan Hukum Islam? Kedua, bagaimana pelaksanaan perjanjian sewa rahim atau surrogate mother yang dibuat dalam bentuk akta Notaris di Indonesia? 


\section{Tujuan Penelitian}

Berdasarkan uraian latar belakang tersebut, tujuan yang hendak dicapai melalui penelitian ini adalah untuk: pertama, untuk mengetahui kedudukan perjanjian sewa rahim atau surrogate mother menurut Kitab Undang-Undang Hukum Perdata dan Hukum Islam; kedua, untuk menganalisis pelaksanaan perjanjian sewa rahim atau surrogate mother yang dibuat dalam bentuk akta Notaris di Indonesia.

\section{Metode Penelitian}

Penelitian ini merupakan penelitian hukum normatif yang menggunakan metode pendekatan berupa pendekatan perundang-undangan (statue approach). Pendekatan perundang-undangan (statute approach) ialah suatu pendekatan yang dilakukan dengan menelaah semua undang-undang dan regulasi yang bersangkut paut dengan isu hukum yang sedang ditangani. ${ }^{8}$

\section{Hasil Penelitian dan Pembahasan}

\section{Kedudukan Perjanjian Sewa Rahim atau Surrogate Mother menurut Kitab Undang-Undang Hukum Perdata dan Hukum Islam}

Pada awa perkembangannya, surrogate mother terjadi karena pihak isteri tidak bisa mengandung karena sesuatu hal yang terjadi pada rahimnya sehingga peran si isteri dialihkan kepada wanita lain untuk menggantikan fungsinya sebagai seorang ibu dalam mengandung dan melahirkan, baik dengan imbalan materi maupun sukarela. Perkembangan selanjutnya terjadi karena pergeseran makna dan substansi, dari substansi awal sebagai alternatif kelainan medis (karena cacat bawaan atau karena penyakit) yang ada ke arah sosial dan eksploitasi nilai sebuah rahim, yang mana pihak penyewa bukan lagi karena alasan medis, tetapi sudah beralih ke alasan kosmetik dan estetika. Sementara bagi pihak yang disewa akan menjadikannya sebagai suatu ladang bisnis baru dengan menyewakan rahimnya sebagai alat mencari nafkah (terutama pada masyarakat yang ekonominya rendah) seperti yang terjadi di negara India, Bangladesh, dan Cina. Negara tersebut difasilitasi oleh pemerintah setempat dengan membuatkan sebuah pusat untuk model sewa rahim termasuk dengan pengurusan visa khusus dan visa medis. ${ }^{9}$

Sewa rahim di India telah memberikan pemasukan negara setiap tahunnya sebesar US\$ 445 atau sekitar Rp. 4.000.000.000.000,00. Wanita di India melakukan

8Peter Mahmud Marzuki, Penelitian Hukum, Cetakan Keduabelas, Prenadamedia Group, Jakarta, 2016, hlm. 133.

${ }^{9}$ Dezriza Ratman, Op. Cit., hlm. 38. 
sewa rahim untuk memperbaiki ekonomi keluarga. Pemerintah India telah melegalkan sewa rahim dengan membuat semacam perkumpulan untuk sewa rahim. Bahkan pemerintah India juga membuat visa khusus atau visa medis untuk memfasilitasi orang yang datang untuk keperluan sewa rahim. Berbeda dengan di India, para ibu pengganti di Amerika Serikat melakukannya karena ingin bisa mendapatkan pengalaman mengandung. Mereka yakin, dengan mengandung maka mereka bisa belajar mengatasi masalah emosi dan memupuk naluri keibuan sekaligus dapat membantu para isteri yang ingin memiliki anak. ${ }^{10}$

Pertanyaan yang muncul kemudian adalah bagaimana pengaturan surrogate mother di Indonesia mengingat berbagai macam permasalahan yang dihadapi oleh pasangan suami-isteri yang belum bisa mendapatkan keturunan yang diakibatkan oleh beberapa alasan ataupun kedudukan surrogate mother sebagai sumbangsih bagi pendapatan negara. Terkait hal ini, perlu dilakukan kajian lebih dalam mengenai pelaksanaan atau praktik surrogate mother di Indonesia berdasarkan Kitab Undang-Undang Hukum Perdata (KUHPerdata) dan juga ketentuan Hukum Islam (mengingat Indonesia merupakan negara dengan mayoritas penduduk beragama Islam dan juga hukum Islam merupakan salah satu sumber hukum yang diakui di negara ini).

Aspek perjanjian pada praktik surrogate mother yang dimaksud dalam hal ini hukum perjanjian yang sah di Indonesia berdasarkan hukum perikatan nasional yang mengacu pada Kitab Undang-Undang Hukum Perdata (KUHPerdata), yaitu terdapat 2 belah pihak yang saling mengikat satu sama lain dimana pihak yang satu memberikan jasa/prestasi (wanita surrogate) dan pihak lainnya memberikan bayaran atau imbalan materi (orang tua biologis). Perjanjian atau perikatan ini didasari oleh jasa yang diberikan ibu pengganti (surrogate mother) yang menerima embrio dari orang tua biologis dan bersedia mengandung serta melahirkan bayi yang dilahirkan kepada orang tua biologisnya.

Ditinjau dari Pasal 1313 KUHPerdata yang menyebutkan, "sesuatu perbuatan dimana seseorang atau beberapa orang mengikatkan dirinya kepada seseorang atau beberapa orang lain", praktek surrogate mother sudah dapat dikatakan sebagai suatu bentuk perjanjian yaitu peristiwa dimana seseorang berjanji (orang tua biologis) kepada seorang lain (wanita surrogate) atau dimana dua orang itu saling berjanji untuk melaksanakan sesuatu hal (embryo transfer). Jadi, ada suatu hubungan antara dua orang tersebut yang dinamakan perikatan. Dengan demikian, perjanjian itu menerbitkan suatu perikatan antara dua orang

${ }^{10}$ Majalab Online Femina, "Kontroversi Surrogate Mother" dalam https://www.femina.co.id/article/ kontroversi-surrogate-mother, Edisi 2 Agustus 2011, Akses 23 Mei 2020. 
yang membuatnya dimana bentuk perjanjiannya adalah suatu rangkaian perkataan yang mengandung janji-janji atau kesanggupan yang diucapkan atau ditulis. ${ }^{11}$

Pasal 1233 KUHPerdata mengatur bahwa tiap-tiap perikatan dilahirkan baik karena perjanjian, maupun karena undang-undang. Terkait hal ini, perjanjian sebagai sumber perikatan apabila dilihat dari bentuknya dapat berupa perjanjian tertulis maupun tidak tertulis, serta yang berasal dari undang-undang saja atau undang-undang karena adanya perbuatan manusia. Pada kasus surrogate mother, perikatan terjadi antara orang tua biologis melakukan suatu perjanjian dengan seorang wanita untuk mengandung dan melahirkan anaknya sehingga berdasarkan Pasal 1313 dan 1233 KUHPerdata tersebut, semua yang tercantum atau yang diperjanjikan merupakan undang-undang bagi mereka, yang dapat dikatakan sebagai unsur suatu perjanjian seperti menentukan prestasi yang dilaksanakan, hak dan kewajiban masing-masing pihak, bentuk dan isi perjanjian, tujuan dan waktu perjanjian serta syarat-syarat tertentu sebagai isi perjanjian. Pada kasus surrogate mother, misal: ${ }^{12}$

1) Prestasi, yaitu mengandung, melahirkan, dan menyerahkan bayi yang dikandung wanita surrogate mother kepada orang tua biologis.

2) Hak dan kewajiban masing-masing pihak: sesuai dengan kesepakatan yang diajukan masing-masing pihak, dimana hak orang tua biologis adalah kewajiban wanita surrogate dan sebaliknya, misal:

a) Hak orang tua biologis: wanita surrogate harus menjaga kandungannya sampai melahirkan dan menyerahkan bayinya.

b) Kewajiban orang tua biologis: membayar imbalan kepada wanita surrogate untuk pembiayaan selama hamil, bersalin, dan jasa.

3) Bentuk perjanjian yaitu tertulis atau tidak tertulis (biasanya tertulis).

4) Isi perjanjian meliputi jumlah biaya yang harus dibayar, waktu penyerahan bayi, (apakah sehabis lahir atau disusui terlebih dahulu), proses pembuatan akta kelahiran dengan data orang tua biologis atau dalam bentuk adopsi.

5) Syarat-syarat tertentu: misalnya pemeriksaan kesehatan lengkap bagi wanita calon surrogate, wanita surrogate, status perkawinan, riwayat penyakit, dan persalinan wanita surrogate dan lain-lain sesuai dengan kesepakatan kedua belah pihak.

Pasal 1234 KUHPerdata menyatakan jenis perjanjian yang berlaku pada kedua belah pihak pada kasus surrogate mother adalah dalam bentuk jasa, yaitu berbuat sesuatu, dengan bunyi pasalnya sebagai berikut, "tiap-tiap perikatan adalah memberikan sesuatu, atau untuk tidak berbuat sesuatu", sehingga semua 
itu dinyatakan sebagai prestasi yang dapat berbentuk barang dan jasa. Adapun syarat sahnya suatu perjanjian yang diatur dalam Pasal 1320 KUHPerdata ada 4 yang meliputi mengenai pihak-pihak yang berjanji dan isi perjanjiannya itu sendiri, yaitu pertama, kesepakatan mereka yang mengikatkan dirinya yaitu adanya kesepakatan antara orang tua biologis dan wanita surrogate. Kedua, kecakapan untuk membuat suatu perikatan, yaitu masing-masing minimal sudah berusia 21 tahun atau belum 21 tahun tapi sudah pernah menikah (wanita surrogate) untuk dapat melakukan perbuatan hukum, tidak dalam pengampunan dan tidak cacat mental.

Ketiga, suatu pokok persoalan tertentu, yaitu isi perjanjian berupa prestasi yang akan diberikan oleh wanita surrogate berupa bersedia mengandung, melahirkan, dan menyerahkan bayinya kepada orang tua biologis dan imbalan materi yang diberikan oleh orang tua biologis. Dan keempat, suatu sebab yang tidak terlarang, yaitu objek perjanjian tidak boleh bertentangan dengan undangundang (hukum) yang berlaku, kesusilaan, dan ketertiban umum. Apabila suatu perjanjian yang dibuat tidak memenuhi syarat subjektifnya (adanya kesepakatan dan kecakapan bertindak, yaitu unsur ke-1 atau ke-2 Pasal 1320 KUHPerdata), perjanjian dapat dibatalkan (vernietigbaar, voidable). Sedangkan apabila syarat objektif yang tidak dipenuhhi, maka perjanjian itu batal sendirinya demi hukum (Nietig van Rechtswegw, Null and Void).

Pada kasus surrogate mother untuk syarat subjektifnya sudah memenuhi syarat, yaitu adanya pihak yang bersepakat dan cakap untuk melaksanakan isi perjanjian tersebut, tetapi untuk syarat objektifnya, praktik surrogate mother terganjal pada syarat yang ke-4, yaitu pada "adanya sebab yang halal" karena ada beberapa sebab yang menyatakan bahwa perjanjian yang dibuat pada kasus surrogate mother harus batal sendirinya demi hukum (Nietig van Rechtswegw, Null and Void) setelah mendapatkan keputusan pengadilan dan keadaan dikembalikan kepada posisi semula dimana dianggap tidak ada perjanjian. Terkait dengan tidak terpenuhinya syarat adanya sebab yang halal pada praktik surrogate mother di Indonesia, yang diakibatkan karena melanggar peraturan perundang-undangan yang ada (hukum positif), yakni pertama, Pasal 127 ayat (1) Undang-Undang Republik Indonesia Nomor 36 Tahun 2009 tentang Kesehatan, yang menyebutkan bahwa "upaya kehamilan di luar cara alamiah hanya dapat dilakukan oleh pasangan suami-isteri yang sah. Kedua, Peraturan Menteri Kesehatan Republik Indonesia Nomor 73/Menkes/PER/II/1999 tentang Penyelenggaraan Pelayanan Teknologi Reproduksi Buatan. Ketiga, SK Dirjen Yan Medik Depkes RI Tahun 2000 tentang Pedoman Pelayanan Bayi Tabung di Rumah Sakit. 
Pelaksanaan praktik surrogate mother di Indonesia dianggap bertentangan dengan kesusilaan karena tidak sesuai dengan norma moral dan adat istiadat atau kebiasaan umumnya masyarakat Indonesia atau di lingkungannya dan bertentangan dengan kepercayaan yang dianut salah satu agama (Islam) karena terdapat unsur pokok yang mengharamkan praktik surrogate mother, yaitu unsur zina. Selain itu, praktik surrogate mother termasuk dalam kategori bertentangan dengan ketertiban umum sebab akan menjadi pergunjingan di dalam masyarakat sehingga wanita surrogate besar kemungkinan akan dikucilkan dari pergaulan. Tindakan pengucilan tersebut sudah tentu pandangan masyarakat Indonesia secara umum yang menganggap bahwa praktik surrogate mother merupakan tindakan yang bertentangan dengan fitrah perempuan dengan adat atau budaya timur yang dianut sehingga ibu surrogate mendapat pandangan yang buruk dari masyarakat.

Ajaran syariat Islam mengajarkan untuk tidak boleh berputus asa dan menganjurkan untuk senantiasa berikhtiar (usaha) dalam menggapai karunia Allah swt. Terkait hal ini, didalam ajaran Islam dikenal Maqashid asy-syariah (tujuan syariah Islam) dimana salah satunya yaitu hifdz an-nasl (memelihara fungsi dan kesucian reproduksi) bagi kelangsungan dan kesinambungan generasi umat manusia. Allah berfirman dalam QS Al-Insyirah (94:5-6) yaitu maka ketahuilah di setiap masalah pasti disertai jalan keluar, ketahuilah bahwa disetiap masalah disertai jalan keluar. Islam juga mengajarkan agar setiap wanita hendaknya menerima kekurangannya sebagai seorang wanita yang tidak bisa melahirkan keturunan, seperti yang tertulis dalam firman Allah SWT. QS Asy-Syu'ara (26: 4950), yaitu kepunyaan Allah kerajaan langit dan bumi. Ia ciptakan apa yang ia kehendaki. Ia karuniakan kepada siapa yang ia berkenan anak-anak perempuan. Dan Ia karuniakan kepada siapa yang ia berkenan anak-anak laki-laki. Atau Ia anugrahi mereka (dua jenis) laki-laki dan perempuan. Dan Ia jadikan mandul siapa yang Ia kehendaki. Sungguh, Ia Mahatahu, Mahakuasa.

Para ulama mengharamkan penggunaan taknologi bayi tabung dari pasangan suami isteri yang dititipkan di rahim perempuan lain sebagaimana ditegaskan dalam fatwa MUI Nomor: Kep-952/MUI/1990 tentang Inseminasi buatan/Bayi tabuni yang menyebutkan bahwa inseminasi buatan/bayi tabung dengan sperma dan ovum yang diambil secara muhtaram dari pasangan suami istri untuk istri-istri yang lain hukumnya haram/tidak dibenarkan dalam Islam. Beberapa pengaturan lainnya yaitu sebagai berikut:

a. Menurut Fatwa MUI (Komisi Fatwa tanggal 13 Juni 1979), Dewan Pimpinan Majelis Ulama Indonesia memfatwakan sebagai berikut: ${ }^{13}$

${ }^{13}$ http://anugerah.hendra.or.id., Akses 2 September 2020. 
1) Bayi tabung dengan sperma clan ovum dari pasangan suami istri yang sah hukumnya mubah (boleh), sebab hak ini termasuk ikhtiar berdasarkan kaidah-kaidah agama;

2) Bayi tabung dari pasangan suami istri dengan titipan rahim istri yang lain (misalnya dari istri kedua dititipkan pada istri pertama) hukumnya haram berdasarkan kaidah Sadd az-azariah, sebab hal ini akan menimbulkan masalah yang rumit dengan kaitannya dengan masalah warisan (khususnya antara anak yang dilahirkan dengan ibunya yang mempunyai ovum dan ibu yang mengandung kemudian melahirkannya, dan sebaliknya);

3) Bayi tabung dari sperma yang dibekukan dari suami yang telah meninggal dunia hukumnya haram berdasarkan kaidah Sadd az-zariah, sebab hal ini akan menimbulkan masalah yang pelik, baik dalam kaitannya dengan penentuan nasab maupun dalam kaitan dengan kewarisan;

4) Bayi tabung yang sperma dan ovumnya diambil dari selain pasangan suami istri yang sah hukumnya haram, karena statusnya sama denagn hubungan kelamin antar lawan jenis di luar pernikahan yang sah (zina), berdasarkan kaidah Sadd az-zariah, yaitu untuk menghindarkan perbuatan zina yang sesungguhnya.

b. Fatwa Majelis Mujamma' Fiqih Islami, menetapkan sebagai berikut:14

1) Lima perkara berikut diharamkan dan terlarang sama sekali, karena dapat mengakibatkan percampuran nasab dan hilangnya hak orang tua serta perkara perkara lain yang dikecam oleh syariat.

a) Sperma yang diambil dari pihak lelaki disemaikan kepada indung telur pihak wanita yang bukan suaminya kemudian dicangkokkan ke dalam rahim istrinya.

b) Indung telur yang diambil dari pihak wanita yang disemaikan kepada sperma yang diambil dari pihak lelaki yang bukan suaminya kemudian dicangkokkan ke dalam rahim si wanita.

c) Sperma dan indung telur yang disemaikan tersebut diambil dari sepasang suami istri, kemudian dicangkokkan ke dalam rahim wanita lain yang bersedia mengandung persemaian benih mereka tersebut.

d) Sperma dan indung telur yang disemaikan berasal dari lelaki dan wanita lain kemudian dicangkokkan ke dalam rahim si istri.

e) Sperma dan indung telur yang disemaikan tersebut diambil dari seorang suami dan istrinya, kemudian dicangkokkan ke dalam istrinya yang lain.

2) Dua perkara berikut ini yang boleh dilakukan jika memang sangat dibutuhkan dan setelah memastikan keamanan dan keselamatan yang harus dilakukan sebagai berikut:

a) Sperma tersebut diambil dari si suami dan indung telurnya diambil dari isterinya, kemudian disemaikan dan dicangkokkan ke dalam rahim istrinya.

b) Sperma si suami diambil kemudian disuntikkan ke dalam rahim isterinya untuk disemaikan. 
Hasil dari ijtihad tersebut mengharamkan penggunaan teknik bayi tabung yang menggunakan sperma dan ovum dari pasangan suami istri lalu embrionya ditransplantasikan ke dalam rahim wanita lain. Dengan demikian jelaslah status anak yang dilahirkan oleh istri yang lain sebagai anak zina dan para ulama menegaskan, di kemudian hari hal itu akan menimbulkan masalah yang rumit kaitannya dengan warisan. Islam juga mengajarkan dalam melaksanakan suatu perjanjian terhadap sesama umat manusia wajib didasarkan pada nilai-nilai keadilan yang harus ditegakkan dan hal tersebut menjadi prinsip pokok untuk melakukan suatu kegiatan perjanjian. Melakukan suatu perjanjian tidak diperbolehkan dengan melakukan penipuan, pertaruhan/perjudian, pemaksaan ataupun mengambil hak milik orang lain dengan cara-cara bathil. Demikian halnya praktik surrogate mother apabila dianggap sebagai suatu tindakan perjanjian antara masing-masing pihak demi suatu tujuan yang menimbulkan hak dan kewajiban bagi setiap pihak yang terkait, dapat dikategorikan sebagai suatu tindak yang mengandung unsur pertaruhan/perjudian atau gharar.

Praktik surrogate mother dapat dikategorikan sebagai suatu perjanjian yang yang mengandung unsur gharar sebab objek yang diperjanjikan belum ada ( $\left.m a^{\prime} d u m\right)$. Tidak adanya kemampuan wanita surrogate untuk menyerahkan objek akad pada waktu terjadi akad, baik objek akad tersebut sudah ada ataupun belum ada (bai' al-ma'dum). Selain praktik surrogate mother, salah satu contohnya adalah menjual ikan yang masih di dalam laut atau burung yang masih di udara. Hal ini didasarkan atas hadist Rasulullah Saw yaitu janganlah kamu menjual ikan yang masih di dalam air, karena itu adalah gharar.

\section{Pelaksanaan Perjanjian Sewa Rahim atau Surrogate Mother yang Dibuat dalam Bentuk Akta Notaris di Indonesia}

Praktek surrogate mother dilarang oleh hukum di Indonesia, tetapi ternyata praktik surrogate mother sudah banyak dilakukan secara diam-diam dan tertutup di kalangan keluarga. Pertanyaan yang timbul selanjutnya adalah bagaimana bentuk pelaksanaan perjanjian surrogate mother apabila ada pihak yang ingin menuangkan dalam bentuk akta Notaris. Notaris adalah pejabat umum yang berwenang untuk membuat akta otentik sejauh pembuatan akta otentik tertentu tidak dikhususkan bagi pejabat umum lainnya. Pembuatan akta otentik ada yang diharuskan oleh peraturan perundang-undangan dalam rangka menciptakan kepastian, ketertiban, dan perlindungan hukum. Selain akta otentik yang dibuat oleh atau di hadapan Notaris, bukan saja karena diharuskan oleh peraturan perundang-undangan, tetapi juga karena dikehendaki oleh para pihak yang berkepentingan untuk memastikan hak dan kewajiban para pihak demi 
kepastian, ketertiban, dan perlindungan hukum bagi pihak yang berkepentingan sekaligus, bagi masyarakat secara keseluruhan. ${ }^{15}$

Produk dari Notaris sebagai alat bukti terkuat dan terpenuh mempunyai peranan penting dalam setiap hubungan hukum dalam kehidupan masyarakat. Didalam berbagai hubungan bisnis, kegiatan di bidang perbankan, perjanjian sewa menyewa, pertanahan, kegiatan sosial, kewarisan, dan lain-lain. Kebutuhan akan pembuktian tertulis berupa akta otentik makin meningkat sejalan dengan berkembangnya tuntutan akan kepastian hukum dalam berbagai hubungan ekonomis dan sosial, baik pada tingkat nasional, regional, maupun global.

Pejabat umum merupakan suatu jabatan yang disandang atau diberikan kepada mereka yang diberi wewenang oleh aturan hukum dalam pembuatan akta otentik. Notaris sebagai pejabat umum kepadanya diberikan kewenangan untuk membuat akta otentik. Oleh karena itu Notaris sudah pasti pejabat umum, tetapi pejabat umum belum tentu Notaris, karena pejabat umum dapat disandang pula oleh Pejabat Pembuat Akta Tanah (PPAT) atau Pejabat Lelang. ${ }^{16}$

Mengenai pekerjaan Notaris, A.G. Lubbers dalam bukunya Het Notariat menyatakan bahwa pertama, otentik berarti bahwa keaslian (ketulenan) ketetapanketetapan tulisan itu adalah pasti, kedua, seorang Notaris tidak hanya menangani ketentuan-ketentuan peraturan jabatan Notaris (mengenai cara membuat dan membentuk suatu akta) ia menanggapi keseluruhan hukum perdata, yaitu hukum yang harus mengatur hubungan antara orang-orang sipil, dan ketiga, seorang Notaris harus mendengar lebih lama dan memberi nasehat sependek mungkin. ${ }^{17}$

Wewenang yang harus dimiliki oleh Notaris hanya diperkenankan untuk menjalankan jabatannya pada yuridiksi/wilayah hukum yang telah ditentukan dan ditetapkan dalam Undang-Undang Jabatan Notaris. Apabila ketentuan itu tidak dipatuhi maka akan menimbulkan akibat hukum yaitu akta yang dibuat Notaris dapat menjadi akta di bawah tangan dan akta tersebut dapat dibatalkan atau batal demi hukum.

Praktik perjanjian sewa rahim (surrogate mother) dapat diklasifikasikan sebagai suatu tindakan yang bertentangan dengan peraturan perundangundangan yang ada dan bertentangan dengan ketertiban umum serta kesusilaan, hal inilah yang harus diperhatikan oleh Notaris dalam memberikan pelayanan hukum berupa pembuatan akta otentik apabila ada penghadap atau klien yang ingin dibuatkan akta Notaris terhadap perjanjian sewa rahim (surrogate mother) yang dilakukannya. Suatu perjanjian yang tidak memenuhi syarat objektif, yaitu

15 M. Luthfan Hadi Darus, Hukum Notariat dan Tanggungjawab Jabatan Notaris, Cetakan Pertama, Yogyakarta, UII Press, 2017, hlm. 7.

${ }^{16}$ Syafran Sofyan, Notaris Openbare Ambtenaren, dalam http://www.Jimly School.com, Akses 21 Mei 2020.

${ }^{17}$ Tan Thong Kie, Studi Notariat dan Serba Serbi Praktek Notaris, Ichtiar Baru Van Hoeve, Jakarta, 2007, hlm. 461. 
objeknya tidak tertentu dan kausa yang terlarang, maka perjanjian tersebut batal demi hukum.

Pasal 1333 BW mengatur bahwa suatu perjanjian harus mempunyai objek tertentu yang artinya suatu perjanjian harus mempunyai sebagai pokok suatu barang yang paling sedikit ditentukan jenisnya yang di kemudian hari jumlah (barang) tersebut dapat ditentukan atau dihitung. Pasal 1335 BW menegaskan bahwa suatu perjanjian tanpa sebab atau yang telah dibuat karena suatu sebab yang palsu atau terlarang, maka perjanjian tersebut tidak mempunyai kekuatan. Hal ini membuktikan bahwa setiap perjanjian harus mempunyai kausa yang halal, tetapi menurut Pasal 1336 BW, jika dinyatakan sesuatu sebab, tetapi ada sesuatu sebab yang halal ataupun jika ada sesuatu sebab lain daripada yang dinyatakan persetujuannya namun demikian adalah sah.

Suatu sebab adalah terlarang apabila dilarang oleh undang-undang atau apabila berlawanan dengan kesusilaan atau ketertiban umum (Pasal 1337 BW). Dengan demikian suatu perjanjian batal demi hukum jika tidak mempunyai objek tertentu yang dapat ditentukan dan mempunyai sebab yang dilarang oleh undang-undang atau berlawanan dengan kesusilaan atau ketertiban umum. Oleh sebab itu, apabila ada Notaris yang tetap menuangkan ke dalam akta Notaris terhadap suatu perjanjian sewa rahim (surrogate mother), akta tersebut menjadi batal demi hukum. Notaris yang diperhadapkan oleh klien atau penghadap yang ingin dibuatkan akta Notaris terkait perjanjian sewa rahim (surrogate mother) yang dilakukannya maka Notaris tersebut dapat memberikan penyuluhan hukum mengenai pelaksanaan sewa rahim yang ada di Indonesia dan menyarankan kepada klien tersebut untuk mengajukan penetapan oleh Pengadilan Negeri dimana klien tersebut melakukan perjanjian sewa rahim tersebut.

\section{Penutup}

Sewa rahim (surrogate mother) tidak bisa dilakukan di Indonesia karena melanggar Undang-Undang Republik Indonesia Nomor 1 Tahun 1974 tentang Perkawinan yang mengatur bahwa untuk mendapatkan keturunan yang sah harus ada ikatan perkawinan hal ini berlaku jika wanita surrogate-nya berstatus janda atau gadis. Sewa rahim juga melanggar Pasal 72 (b) Undang-Undang Republik Indonesia Nomor 36 Tahun 2009 tentang Kesehatan. Selain itu, perjanjian/perikatan sewa rahim dalam perspektif hukum perdata dianggap tidak sah karena menyalahi hakikat dari objek perjanjian/perikatan.

Sewa rahim dalam perspektif hukum Islam hukumnya haram menurut pandangan mayoritas ulama di Indonesia terbukti dengan adanya ketetapan fatwa maupun pendapat individu yang mengatakan bahwa sewa rahim haram 
hukumnya dalam Islam disebabkan beberapa alasan yang berdasar pada AlQuran. Selain itu, praktek surrogate mother di Indonesia dianggap bertentangan dengan kesusilaan karena tidak sesuai dengan norma moral dan adat-istiadat atau kebiasaan umumnya masayarakat Indonesia. Notaris yang diperhadapkan oleh klien atau penghadap yang ingin dibuatkan akta Notaris terkait perjanjian sewa rahim (surrogate mother) yang dilakukannya, Notaris tersebut dapat memberikan penyuluhan hukum mengenai pelaksanaan sewa rahim yang ada di Indonesia dan menyarankan kepada klien tersebut untuk mengajukan penetapan oleh Pengadilan Negeri dimana klien tersebut melakukan perjanjian sewa rahim tersebut.

Pemerintah harus merespon terhadap fenomena praktik perjanjian sewa rahim (surrogate mother) di Indonesia dengan membuat suatu regulasi atau aturan hukum yang mengikat dan tegas, mengingat adanya kasus sewa rahim (surrogate mother) yang dilakukan secara diam-diam. Selain itu, Notaris dalam melaksanakan tugas jabatannya sebagai Notaris harus betul-betul menerapkan prinsip pelaksanaan tugas jabatan Notaris yang baik, dengan memahami aturan hukum yang berlaku agar dapat menjamin kualitas produk hukum yang dibuatnya dan tidak begitu saja menolak klien atau masyarakat yang datang kepadanya, sebab ada kewajiban juga bagi Notaris untuk memberikan penyuluhan hukum kepada masayarakat.

\section{Daftar Pustaka}

\section{Buku}

Husairi, Ahmad, Kontribusi Embriologi dalam Penetapan Hukum Fiqih Kehamilan, Cetakan Pertama, Pustaka Banua, Yogyakarta, 2007

Luthfan Hadi Darus, M., Hukum Notariat dan Tanggungjawab Jabatan Notaris, Cetakan Pertama, Yogyakarta, UII Press, 2017.

Mahmud Marzuki, Peter, Penelitian Hukum, Cetakan Keduabelas, Prenadamedia Group, Jakarta, 2016.

Ratman, Dezriza, Surrogate Mother Dalam Perspektif Etika dan Hukum; Bolehkah Sewa Rahim di Indonesia?, PT. Media Elex Komputindo, Jakarta, 2012

Seri Nabahan, Radin bt. Ahmad Zabidi, 2007, Penyewaan Rahim Menurut Pandangan Islam, Pustaka Utama, Bandung, 2007

Soetojo Prawirohamidjojo, R., Pluralisme Dalam Perundang-Undangan Perkawinan di Indonesia, Airlangga University Press, Surabaya 1998.

Thong Kie, Tan, Studi Notariat dan Serba Serbi Praktek Notaris, Ichtiar Baru Van Hoeve, Jakarta, 2007.

\section{Peraturan Perundang-undangan}

Kitab Undang-Undang Hukum Perdata. 
Kompilasi Hukum Islam.

Undang-Undang Nomor 5 Tahun 1986 tentang Peradilan Tata Usaha Negara

Undang-Undang Nomor 3 Tahun 2006 tentang Perubahan Atas Undang-Undang Nomor 7 Tahun 1989 tentang Peradilan Agama

Undang-Undang Nomor 2 Tahun 2014 tentang Perubahan Atas Undang-Undang Nomor 30 Tahun 2004 tentang Jabatan Notaris

Permenkumham Nomor M.02.PR.08.10 Tahun 2004 tentang Tata Cara Pengangkatan Anggota, Pemberhentian Anggota, Susunan Organisasi, Tata Kerja, dan Tata Cara Pemeriksaan Majelis Pengawas

Kode Etik Ikatan Notaris Indonesia

\section{Data Elektronik}

Majalah Online Femina, "Kontroversi Surrogate Mother" dalam https://www.femina.co.id/article/ kontroversi-surrogate-mother, Edisi 2 Agustus 2011, Akses 23 Mei 2020

http:/ / anugerah.hendra.or.id., Akses 2 September 2020

Syafran Sofyan, Notaris Openbare Ambtenaren, dalam http://www.Jimly School.com, Akses 21 Mei 2020. 